\title{
„OGIEŃ I PIASEK” — O OSTATNIM OKRESIE ŻYCIA I TWÓRCZOŚCI NORWIDA NA PODSTAWIE ELEGII NA ZGON POEZJI
}

Niepodobna biografii Norwida podzielić na sztywne okresy twórczości. Jednakże można zastanowić się nad przełomowymi datami w życiu poety i postawić pytanie o ich wpływ na jego dzieła. Współcześnie odchodzimy stopniowo od Barthesowskiej „śmierci autora” - mamy świadomość, że nie można oddzielić dzieła od jego twórcy, tym samy również od jego biografii. Wychodząc z tego założenia, warto postawić tezę, że ostatni okres w życiu twórcy Promethidiona datować można od 1877 roku.

Na początku roku Norwid był pełen optymizmu — w połowie stycznia wysłał swoje bagaże do Florencji. Postanowił definitywnie opuścić Paryż i przenieść się do Włoch. Powodów mogło być wiele. Rok wcześniej u rodziny Wagnerów poznał Marię Sadowską. Znajomość z nią szybko przekształciła się w gwałtowny i niebezpieczny romans - Sadowska była mężatką. Jako najlepszy sposób na wydostanie się z kłopotliwej sytuacji Norwid uznał wyjazd do Włoch, dlatego już w tym roku rozpoczął działania, których celem było ostateczne pożegnanie z Paryżem. Wspomniana przygoda z Sadowską jest jednym z dwóch powodów planowanego przez poetę wyjazdu. $\mathrm{Na}$ początku 1876 roku Norwid opuścił szpital. Osłabiony i walczący z gruźlicą, w zmianie klimatu widział ostatnią szansę na uratowanie zdrowia.

Styczeń 1877 roku Norwid spędził na oczekiwaniu spodziewanej pożyczki od księcia Władysława Czartoryskiego. W jej uzyskaniu miał pomóc poecie Bronisław Zaleski — ówcześnie najbliższy przyjaciel Norwida. Niestety, jak można domyślić się z korespondencji ${ }^{1}$, Zaleski zawiódł — Norwid nie otrzymał pożyczki. Poeta musiał zapomnieć nie tylko o wyjeździe do Włoch; pod znakiem zapytania stanęło również jego dalsze życie w Paryżu. Rok wcześniej zmuszony był zlikwidować mieszkanie i sprzedać meble, by pokryć część wierzytelności. Schorowany i zadłużony, musiał pogodzić się z całkowitą utratą niezależności. Załamany, zamieszkał 9 lutego w maleńkiej celi

\footnotetext{
* Mateusz Grabowski — doktorant w Katedrze Literatury i Tradycji Romantyzmu. Naukowo zajmuje się polskim i francuskim romantyzmem. Od 2014 roku redaktor naczelny czasopisma teatralnego „Proscenium" wydawanego przez Teatr Nowy im. Kazimierza Dejmka w Łodzi.

${ }^{1}$ Zob. list Norwida do Zalewskiego z 18 stycznia 1877 wraz z przypisami J. W. Gomulickiego [w:] C. Norwid, Pisma wszystkie, zebrał, tekst ustalił, wstępem i uwagami krytycznymi opatrzył J. W. Gomulicki, Warszawa 1971-1976, t. 10, s. 89-92 (w dalszej części wywodu skrót PWsz, jako numer tomu podaje się cyfrę rzymską, a jako numer strony cyfrę arabska).
} 
w Domu św. Kazimierza w podparyskim Ivry. W korespondencji z tego okresu trudno doszukiwać się wzmianek poety związanych z nową sytuacją. Załamany i opuszczony, zamknął się w sobie. Od początku lutego aż do końca roku nie przyjmował nikogo; wycofał się z życia towarzyskiego, które przecież tak bujnie rozkwitało rok wcześniej. Jak już wspomniano, korespondencja z tamtego okresu jest oszczędna — nic nie znamionuje bólu, przez jaki przechodził osamotniony Norwid. Jedyna wzmianka na temat tragizmu jego położenia znalazła się w drugiej części listu do Bronisława Zaleskiego z dnia 21 listopada 1877 (PWsz X 108). Opatrzona nagłówkiem „Na »karteczce do spalenia«", zawiera gorzką refleksję Norwida nad jego ówczesnym położeniem, który napisał, że z każdą godziną coraz boleśniej zdawał sobie sprawę z tragiczności swego losu. $\mathrm{Z}$ ironią napomknął o braku zaledwie tysiąca franków (które miał pożyczyć mu Czartoryski):

Ja po prostu jaśniej, co jesień i co zima, widzę, że się gubię tu — powietrza zmienić nigdy nie mogłem dla lichego braku około tysiąca franków, które robię częściowo, i podobno że nie częściowo zrobię wtenczas, kiedy przyjdzie skronie oprzeć o piasku - Co 24 godzin to jaśniej widząc, nie chcę tego dotykać myślą moją!

Zniszczyć - (PWsz X 109)

Dopiero po paru latach napisał, że ,jest TU lepiej [...] ale gdy tu przybyłem, była tu Botany-Bay"2. Sama prośba, by wspominany wcześniej list do Zaleskiego spalić, wskazuje, jak poufna i intymna była zawarta w nim refleksja.

Rok 1877 można uznać za moment graniczny w życiu Norwida. Świadom biedy, choroby i utraty niezależności, twórca Assunty właśnie w tym roku rozpoczął swoje literackie rozliczenie z rzeczywistością. Napisał wtedy niewiele utworów, głównie kilka wierszy: Na zgon Poezji, Naturalizm, Ciemność, Na smętne wieści z Watykanu. Z prozy były to Dwie aureole i Biografie spóźnione.

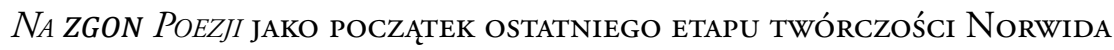

Ramą kompozycyjną wiersza Na zgon Poezji jest śmierć pięknej kobiety — personifikacji Poezji. Zabieg można traktować jako intrygujący koncept, którego celem miało być zintensyfikowanie emocji związanych z kryzysem Poezji. Kryzysem rozumianym dwojako. Na pewno ma on związek z trudną sytuacją emigracyjnych twórców. Wysyłając wiersz do redakcji „Ruchu Literackiego”, Norwid umieścił pod nim dopisek:

Dzienniki polskie głoszą upadek Poezji, cytują, że Adam, Juliusz i Zygmunt musieli swym nakładem wszystko wydawać i opłacać, aby istniało [...]. Żyję — milczę — pamiętam — Vale. (KZT II 652)

Umieszczona uwaga jest dobitnym komentarzem. Jednakże kryzys Poezji nie miał w wypadku Norwida związku tylko z trudną sytuacją materialną twórców i, co gorsza, ignorancją czytelników i krytyki. Warto pamiętać, w jakim okresie postanowił opubli-

\footnotetext{
${ }^{2}$ „Kolonia w Australii, do której deportowano przestępców z Wielkiej Brytanii” za: PWsz X 116.
} 
kować wiersz. Śmierć i pogrzeb Poezji to niejako odniesienie do niego samego - poety pogrzebanego w zakładzie św. Kazimierza. Ostatnia część zacytowanego fragmentu jest zwieńczeniem gorzkiej refleksji. Kiedy poeta pisał o śmierci Poezji, to zaprzeczał swej roli, ukazując swoją zbędność i śmieszność. Mimo wszystko jednak tworzył nadal. To paradoks, ale w ostatnim okresie życia Norwida było ich tym więcej, im bardziej zapadał się w samotność i mizantropię.

Można by na tym etapie zatrzymać się, uznać, że koncept utworu został właściwie wyjaśniony. Za Norwidowskim pomysłem kryje się jednak coś jeszcze. Gomulicki słusznie połączył powstanie utworu ze śmiercią bliskiej przyjaciółki Norwida, a zarazem jednej z najważniejszych postaci w życiu artystycznym wielkiej emigracji — Zofii Węgierskiej. Jak trafnie bowiem zauważyła Anna Siemińska Na zgon Poezji trzeba czytać jako „wiersz politematyczny zbudowany z trzech kunsztownie splecionych wątków treściowych"3. Obok wspomnianej już oceny emigracyjnych realiów życia artystycznego i świadectwa walki autora Assunty z trudną sytuacją materialną, ostatnim z wątków elegii stanie się właśnie hołd złożony autorce Legend historycznych. Wiersz powstał prawdopodobnie w 1869 , tuż po drugim pogrzebie Węgierskiej, lecz ostateczny kształt nadał mu poeta w 1877, tuż przed wysłaniem go do „Ruchu Literackiego”. Żeby zweryfikować tezę Gomulickiego, trzeba się dokładniej przyjrzeć roli, jaką Węgierska pełniła w życiu emigracji oraz jej osobistym relacjom z Norwidem.

Zofia z Kamińskich Węgierska była świetną felietonistką, pisarką i korespondentką paryską, takich czasopism krajowych jak: „Biblioteka Warszawska”, „Czas” i „Bluszcz”. W Paryżu, gdzie na stałe mieszkała od 1850 roku, stworzyła salon literacki mieszczący się w jej mieszkaniu przy rue de Laval. Na coniedzielnych spotkaniach w "Sofiówce” bywali Seweryn Goszczyński, Bronisław Zaleski, Feliks Wrotnowski, Władysław Żeleński. W 1848 spotkała się we Wrocławiu z Juliuszem Słowackim ${ }^{4}$ Łączyła ich bliska przyjaźń, na co wskazuje treść listu poety z września 1848 , w którym zwracał się do Węgierskiej (wtedy jeszcze Mielęckiej) jako do „brata Sofos”. . Pokłosiem ich relacji stał się poemat Dzieje Sofos i Heliona, który miał być jej prezentem ślubnym ${ }^{6}$. Węgierska była znaną i cenioną korespondentką, do ostatnich dni cechowała się wręcz tytaniczną pracowitością. Korespondencja pomiędzy nią a Norwidem (zachowała się jej niewielka część), oraz jej felietony, jak chociażby recenzja Dzieł zebranych Baudelaire’a ogłoszona w Kronice paryskiej (KZT II 423) (napisanej z okazji ukazania się w 1869 Petits poèmes en prose i prac krytycznych L'art romantique), ukazały ją jako erudytkę, indywidualistkę i niezwykle inteligentną kobietę. Nie bez powodu napisał Norwid po jej śmierci:

Społeczeństwo polskie straciło jedną z najznakomitszych kobiet [...] Ale jeżeli to był umysł Polki, który dziewiętnaście lat niepospolitym piórem służył bezimiennie rzeczy ogólnej umysłu, a przy tym jeśli

\footnotetext{
${ }^{3}$ A. Siemińska, Elegia Cypriana Norwida „Na zgon Poezji”, [w:] Liryka Cypriana Norwida, red. P. Chlebowski i W. Toruń, Lublin 2003, s. 442.

${ }^{4}$ Z. Sudolski, Stowacki. Opowieść biograficzna, Warszawa 1996, s. 313.

${ }^{5}$ Korespondencja Juliusza Stowackiego, oprac. E. Sawrymowicz, t. 2, Wrocław 1963, s. 215-216.

${ }^{6}$ Z. Sudolski, dz. cyt., s. 321.
} 
to były ręce, co uszyły sobie sukienki, i wdzięk, który w czterech murach jak w królewskim salonie ugościć najmilej umiał WSZYSTKICH pisarzy, myślicieli, artystów... (PWsz IX 435)

O tym, jak ważną była ona postacią dla poety, świadczą wiersze, których adresatką i muzą stała się Węgierska. Mowa tu o wierszu (Zdawa mi się niekiedy...) (pisanym, jak wskazał Gomulicki, w nastroju po jej śmierci) ${ }^{7}$ oraz $D o \Sigma$, co do którego jednak nie ma pewności, czy jego autorem był faktycznie Norwid ${ }^{8}$. Jednak sama natura relacji pomiędzy Norwidem a Węgierską nie jest oczywista.

Przyjąć należy, że istnieje pewna sugestia, że o ile Węgierska traktowała Norwida jako przyjaciela, o tyle jego uczucia mogły być bardziej skomplikowane. Wskazuje na to korespondencja Węgierskiej do Norwida z 4-5 października 1869 roku, którą można traktować jako odmowę przyjęcia zaręczyn:

Twórczość najwyższa wymaga współpracownictwa dwóch dusz. Takie prawo boże [pisownia oryginalna]. Więc kochać nie jest robota wielka, ale jest boskie ułatwienie boskiej roboty. Nawet do machinalnej twórczości miłość dodaje sił — i zawsze, jak mówi kochanek Normy filozoficznym językiem Hegla: Liebe ist es die Grosses stets gebar.

Kochać się w kimś to jest robota duża, bo wtedy człek tworzy bez współpracownictwa, na chwałę czarta. Ale Ty tak nie kochasz, mój królewiczu — więc powinien byś odklęczeć przynajmniej pół godziny za jeden frazes listu Twojego, którego nie powtórzę, gdyż byłoby to podwójne bluźnierstwo przeciw majestatowi uczucia najwyższego. Dzięki serdeczne za zdrowie-dajne współczucie. Mam się lepiej. Niech Ci Bóg zapłaci za to, co dla mnie czynisz — przeze mnie czy przez kogo lepszego. (KZT II 424)

Niestety, list Norwida, na którego odpowiedzią była zacytowana korespondencja, nie zachował się. Prawdopodobnie został spalony z większością prywatnej korespondencji Węgierskiej przez jej kuzyna Kazimierza Gawrońskiego. Na podstawie samej korespondencji niepodobna dokładnie określić, jak bliskie były stosunki poety z Węgierską. Za możliwością romansu przemawia to, że uczucie przyjaźni między Norwidem a kobietami zwykło przeradzać się, przynajmniej dla niego, w coś więcej (przykładem niech będzie próba oświadczyn Marii Trębickiej, których odrzucenie było początkiem końca ich wieloletniej przyjaźni). Należałoby pozostawić ten fragment biografii Norwida otwarty, chyba że badaczom uda się odnaleźć dowody na poparcie którejś z tez. Istotne jednak, że sam wspomniany list pokazuje, jak bliska i poufała była znajomość poety z Węgierską. Nie tylko dla Norwida.

\footnotetext{
7 Z. Trojanowiczowa, Z. Dambek, E. Lijewska, I. Grzeszczak, przy współudziale J. Czarnomorskiej i M. Pluty, Kalendarz życia i twórczości Cypriana Norwida, t. 1-3, Poznań 2007, t. 1, s. 435. (w dalszej części wywodu skrót KZT, jako numer tomu podaje się cyfrę rzymską, a jako numer strony cyfrę arabska)

${ }^{8}$ KZT I, s. 640. Gomulicki odrzuca autorstwo Norwida, zwracając uwagę na nietypowy, jak na autora Promethidiona, styl wiersza, podpis „Moriturus” oraz styl pisma. Za uznaniem wiersza, jako utworu napisanego przez Norwida, wskazywać może wspomniany podpis (który jest elementem często stosowanego przez poetę pozdrowienia gladiatorów: „Morituri te salutant”), temat wiersza oraz podpis pojawiający się w dopisie: Norwid Cypryan (nie ręką autora). Sam wiersz zresztą znajduje się na odwrocie kartki z adresem Węgierskiej „rue Laval 25”, który zapisany został ręką Norwida. Jak dotąd jednak sprawa autorstwa wiersza pozostała nierozstrzygnięta.
} 
W liście do Bronisława Zaleskiego z 10 listopada 1869 roku poeta przekazuje mu opis snu Węgierskiej. Oto jego fragment:

Tak myśląc i wijąc się na posłaniu, czując twardymi poduszki i puch łabędzi w różowej oponie mniemając ołowiem... usnęłam wreszcie... i wnet dogoniłam Ciebie odchodzącego w cmentarnym korytarzu i wnet wyszliśmy na jasność księżycową, do ogrodów pełnych najmistyczniejszych woni — i tak [...] szliśmy aż do kwitnącego mirtu, gdzieś usiadł i zaczął mi czytać z wielkiej księgi takie prześliczne rzeczy, jakich na ziemi nikt nie wygłasza... Ja byłam zachwycona — wniebowzięta...Ale wnet naszła czarna chmura i lunęła strugami błyskawic [...] I wraz przyleciał ogromny ptak biały, a my, uczepiwszy się jego skrzydeł, ulecieliśmy w powietrze... A potem, potem co było? Alboż to można opisać? Ach! Czemuż ja się obudziłam? (PWsz IX 432-434)

To, co ukryte, niewyrażalne na co dzień, artykułuje dopiero sen, ewokując symboliczne obrazy nieświadomego. Wiedzieli o tym romantycy, więc nie sposób się dziwić, że Norwid traktował bardzo poważnie marzenie Węgierskiej. Trudno analizować wszystkie elementy i interpretować treść snu, ale warto zastanowić się, co wyraża on w warstwie emocjonalnej. Opis sennego spotkania z Norwidem i głęboki żal, że musiało się ono skończyć, pokazuje, jak bliską był jej osobą i jak wiele znaczyła dla niej ich przyjaźń. Norwid miał tego świadomość i odwzajemniał jej uczucia. Nie jest istotny już nawet ich charakter, lecz głębia. Nietrudno więc się domyślić, że w 1869 roku poeta stracił jedną z najbliższych i najważniejszych kobiet w swoim życiu. Dlatego postanowił wyróżnić ją i uhonorować, czyniąc pomiędzy nią a Poezją znak równości.

Wiersz rozpoczął od emocjonalnego wykrzyknienia „Ona umarła!” (PWsz II 200). Od pierwszej strofy czytelnik widzi więź pomiędzy Poezją i jej powiernikiem — ostatnim poetą. Nie bez powodu był on jej jedynym powiernikiem. W szóstym wersie wspomniał o tym, że stał przed jej łożem w godzinie konania. Co więcej, w drugiej strofie to jemu umierająca kazała zasłonić okna. Warto pamiętać, że Norwid był jedną z ostatnich osób, które odwiedziły umierającą Węgierską. Był świadom, że to ostatnie chwile, jakie spędzał ze swoją przyjaciółką. Pisząc o tym, że to „pieniądz i bruliony” (PWsz II 200) doprowadziły do jej agonii, poeta bezpośrednio odniósł się do biografii Węgierskiej. Jak zauważył Gomulicki:

to charakterystyczna aluzja do wyczerpującej pracy literackiej Węgierskiej, która utrzymywała się z pisanina stałych „kronik paryskich” do kilku czasopism krajowych. Wymagało to bezustannego sporządzania „brulionów” (kroniki ukazywały się co miesiąc, w każdym piśmie w trochę innym terminie), zapewniających autorce „pieniądz”, potrzebny na jej skromne życie i odrobinę rozrywek?.

W wierszu Norwida aspekt ekonomiczny stanowi część szerszych rozważań dotyczących dychotomii duch - materia. Zostały one zawarte w ostatnim wersie pierwszej strofy w retorycznym pytaniu: „Czy to [Poezja], co gaśnie, jest duch albo ciało?” (PWsz II 200). Jest to pytanie, które będzie echem rozważań poety nad tym, czym w istocie jest Poezja, a szerzej — sztuka.

${ }^{9}$ C. Norwid, Dzieła zebrane, oprac. Juliusz W. Gomulicki, indeksy M. Gomulicka, t. 2, Warszawa 1966, s. 940. 
Jednym z najważniejszych poematów w polskiej tradycji XIX wieku jest Promethidion. We wstępie autor przyrównał sztukę do „tęczy Wiecznego Jeruzalem” (PWsz III 427) Tym samym odwołał się do uniwersum biblijnego. W Apokalipsie św. Jana pojawiła się fraza dotycząca Nowego Jeruzalem — idealnego porządku, zbawionego świata powracającego do boskiego uniwersum. Norwid wykorzystał ten motyw, łącząc go z tęczą, która w tradycji chrześcijańskiej oznacza przymierze z Bogiem. Sztuka w tym ujęciu staje się spoiwem wertykalnego połączenia pomiędzy bios i logos, sacrum i profanum, sama reprezentując porządek sakralny. To nawiązanie do myśli neoplatońskiej, w której sztuka wyraża to, co święte i która ewokuje elementy świata materialnego. By jednak mogła spełnić swoją rolę, musi być oparta na prawdzie. Tylko taka może konotować wielkie wartości: bohaterstwo, heroizm i zwycięstwo.

Istotną wadą wspomnianego traktatu jest patos, który nie dopuszcza trudnego pytania o kruchość sztuki i poezji. Norwid potrzebował czasu, by wyartykułować ten problem w swej twórczości. To śmierć najbliższej przyjaciółki, wyniszczonej przez tytaniczną pracę, i późniejsze zesłanie poety do zakładu św. Kazimierza, wyostrzyły jego optykę. W analizowanym utworze Poezja, czy w szerszym ujęciu sztuka, ulega atrofii. To, czy jej zgon jest pozorny, wiąże się z odpowiedzią na wspomniane pytanie: czy śmierć Poezji ma aspekt czysto materialny, w którym poeci i twórcy, tacy jak Węgierska, należą do grupy wykluczonych ${ }^{10}$, czy można mówić również o aspekcie duchowym związanym z brakiem refleksji i ignorancją. To, jak się wydaje, najistotniejsze pytanie, które na tym etapie analizy trzeba sobie postawić.

Jak już wspomniano, upersonifikowana Poezja w godzinie konania prosi poetę, by „światło przyćmił, bo uśmiechy kłamie, / Jakby jej w oczy wiosna urągała” (PWsz II 200). Poza metaforyczną dychotomią światłość — ciemność można doszukiwać się czegoś znacznie bardziej ponurego. Przyjąć można, że ów fragment nie jest tylko zapisem agonii, lecz również głębokiej zgryzoty doprowadzającej do depresji. Można zadać sobie pytanie, znając biografię Norwida z tamtego czasu, czy nie utożsamiał się z umierającą. Szczególnie, że umierającą była jego najbliższa w tamtym okresie przyjaciółka. W tym wersie nakładają się dwie lektury utworu, o których wspomniano wcześniej. Cierpienie konającej staje się agonią poety. Umiera jego muza — Poezja, a zarazem jego przyjaciółka i powiernica, a w ostateczności, ginie on sam — poeta wykluczony, odrzucony poza krąg życia społecznego, bo tak należy traktować jego pobyt w przytułku. W konsekwencji, śmierć Poezji to również jego agonia. Relacje poeta — Poezja stały się bolesne i wyniszczające.

Na sześć lat przed powstaniem Promethidiona Norwid napisał przejmujący wiersz Moja piosnka zaczynający się od słów „Źle, źle zawsze i wszędzie” (PWsz I 65). Głównym motywem powracającym w utworze jest „czarna nić”, powoli oplatająca poetę.

\footnotetext{
${ }^{10}$ Norwid łączy chorobę pisarki z jej wyniszczającą pracą i aspektem socjalnym: „Trzy dni przed ostatnim dniem zaszedłem — kaszlała tym samym kaszlem socjalnym, co śp. Zygmunt Kr[asiński]” [w:] KZT II 428.
} 
Można ją interpretować jako jeden z poetyckich obrazów melancholii ${ }^{11}$. Jednakże, jak się wydaje, nie tyle o depresji pisał Norwid, ile właśnie o sztuce i o talencie, który nie dał mu radości, który skazał go na wyśmianie i niezrozumienie, a ostatecznie wpędził w jeszcze większe załamanie. Poeta wyraził to w ostatnich wersach wiersza:

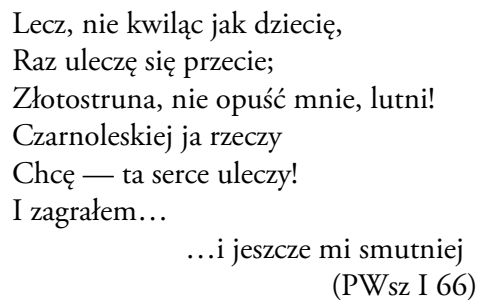

Szukając ratunku w twórczości, poeta skazał się na jeszcze większe cierpienie; tworząc, intensyfikował swój ból. Nie można jednak postawić tezy, iż stosunek Norwida do żywiołu twórczego był oparty tylko na cierpieniu, że jego relacja z Poezją była wręcz toksyczna. Wydaje się, że w tym wierszu Norwid niezwykle szczerze napisał o tym, czym dla niego była sztuka. Tworzenie związane jest z cierpieniem, które, paradoksalnie, uszlachetnia Poezję. Żeby to zauważyć, wystarczy zderzyć sam utwór z otwierającym go mottem z Hamleta. Udający szaleńca (bądź naprawdę już popadający w obłęd) Hamlet powiedział, że to, co czytał, to tylko puste słowa. Puste i trywialne dlatego, że były oderwane od jego cierpienia, książka, o której mówił, okazała się tylko miałką satyrą. To, co szczere, działo się w nim. Jego cierpienie stało się nośnikiem prawdy. Można przyjąć, że z tego samego założenia wyszedł Norwid. Ten pogląd rozwinął zresztą w Promethidionie.

Norwid opatrzył każdy z dwóch dialogów poematu osobnym mottem. Motto Bogumita dotyczy natury i potrzeby cierpienia:

[...] za Zbawicielem z krzyżem swoim, ta jest zasada wszech-harmonii społecznej w Chrześcijaństwie — ten jest tego, co zowią materialnie specjalnościami, rytm i akord... Ta to jest nareszcie tajemnica ruchu sprawiedliwego... (PWsz III 431)

W tym ujęciu cierpienie jest nierozerwalnym elementem sztuki. Warto jednak pamiętać, że w tradycji chrześcijańskiej krzyż symbolizuje zbawienie. Może być ono zyskane tylko przez mękę, która jest warunkiem niezbędnym do osiągnięcia doskonałości. Warto wspomnieć również o ciekawej metaforze, która pojawi się w drugim dialogu Promethidiona:

Ten głos, przez potów, krwi i łez kropelki

Ociekający w sumienia naczynie

Pod narodami, jak w mistyczną skrzynię,

\footnotetext{
${ }^{11}$ Znamienne, że twórcy cierpiący na melancholię obrazowali ją w swoich dziełach, traktując ją niemal jak wyklętą siostrę muz. Do najbardziej znanych wizerunków melancholii należą szklany klosz Sylwii Plath, czarny pies Winstona Churchilla i gwiazda Saturn na rycinie Dürera. Norwidowski obraz melancholii jest równie sugestywny.
} 
Jak wór bajeczny Greków z morskim wiatrem,

Jak ściek pod męczeństw tu amfiteatrem...

(PWsz III 455)

Za ciekawe, choć prawdopodobnie nie do końca zgodne z autorską intencją, trzeba uznać objaśnienie Juliusza W. Gomulickiego, który przestrzeń zaznaczoną w zacytowanym fragmencie zaimkiem "tu” definiował jako rzymskie mieszkanie Stanisława E. Koźmiana lub samego Norwida, gdzie w 1847 roku miałyby odbywać się dyskusje, jakoby odtworzone w poemacie (PWsz III 760-761). Wydaje się, że realne wydarzenia i postaci nie mogą być tak jednoznacznie odnoszone do treści utworu. Bohaterowie dialogów to postaci reprezentujące odmienne stanowiska dotyczące sztuki narodowej i jej powinności, lecz przede wszystkim część z nich to figury symboliczne o potencjale głęboko metafizycznym, jak Bogumił (imię znaczące) lub sam Prometeusz - uosobienie człowieczeństwa, ten, który skupia w sobie całość cywilizacji. Przywołanie przez Norwida rzymskiego amfiteatru - Colosseum, miejsca agonii pierwszych chrześcijan, wraz z faktycznym elementem architektonicznym — specjalnym kanałem odprowadzającym $\mathrm{z}$ areny krew, ma potencjał mistyczny głęboko zakorzeniony w tradycji chrześcijańskiej. W takiej recepcji amfiteatr reprezentuje każdy naród (w kontekście Promethidiona szczególnie polski), w którym cierpienie kumuluje się jako olbrzymi potencjał z czasem doprowadzający do przemiany.

Również w Na zgon Poezji związek cierpienia z Poezją pojawia się w perspektywie chrześcijańskiej. W piątym wersie drugiej strofy poeta wspomniał o znamieniu, które zauważył pod lewą piersią umierającej. Jest to oczywiście jeden ze stygmatów męki Chrystusa. W tym kontekście Poezja nabiera cech mesjanistycznych, w których przekaz martyrologiczny jest dominujący ${ }^{12}$ :

O, byłem smętny, jak dotąd nie bywam,

Gdy mam już cmentarz i na nim kwiat zrywam

(PWsz II 200)

Po tych wersach śmierć Poezji staje się faktem dokonanym. Poeta wydaje się być pogodzony z tragedią — jego emocje wygasają. Pozornie. Pisząc o cmentarnym kwiecie, który zrywa, metaforycznie mówi właśnie o tworzeniu. Jednakże jego twórczość wyrosła na martwym gruncie, na wygasłej, przebrzmiałej manierze poezji katakumb. Jest to niejako zwrot ku programowym ideom wyrażonym przez poprzedników autora Promethidiona. Początkowo Norwid był niezwykle krytyczny wobec tych tendencji, co najdobitniej wyraził w poemacie Ruiny (1863). Niemniej, analizując Na zgon Poezji,

\footnotetext{
${ }^{12}$ Norwidowski mesjanizm, jakże pierwotnie inny od mistycznych filozofii Mickiewicza i Słowackiego, miał wymiar optymistyczny. Cierpienie było tylko elementem niezbędnym do dokonania przemiany. W Na Zgon Poezji dzieje się coś zadziwiającego — aspekt związany z cierpieniem zaczyna podporządkowywać sobie to, co określić można jako wymiar optymistyczny i, wydawałoby się, wcześniej nadrzędny. Nawet jeżeli mowa jest o pewnej nadziei na przemianę, to bliższa jest ona utopijno-transgresyjnym teoriom Mickiewicza (Widzenie, Księgi narodu i pielgrzymstwa polskiego) i wręcz tożsama z filozofią genezyjską Słowackiego (ogień, jako element alchemicznego exaltatio, jakim wcześniej była idea pracy).
} 
można zauważyć zmianę Norwidowskiej optyki. Mesjanistyczny pesymizm właściwy poprzednikom poety najbardziej wyrazistą postać przybrał w jego niedokończonej tragedii Kleopatra i Cezar (1870-1872), która była niejako zapowiedzią poetyki właściwej elegii Na zgon Poezji.

W kolejnej strofie poeta powtórzył frazę rozpoczynającą wiersz. Co ciekawe, pisząc o Poezji, po raz kolejny umieścił jej imię w nawiasie, sugerując tym samym, że nie tylko do niej się odnosił. Dzięki temu zabiegowi widoczna staje się w pełni politematyczność Norwidowskiej elegii. Jak zauważyła Siemińska:

Czytając wiersz Norwida, warto pamiętać o tym, że porównanie Zofii do poezji to coś więcej niż tylko hołd złożony jej pamięci czy stereotypowy komplement, często pojawiający się w tekstach, którym patronuje konwencja epitafium. Dzięki zestawieniu trzech różnych wątków tematycznych, które wzajemnie na siebie oddziałują, Norwid zintensyfikował wymowę utworu jako całości. Pokazał, że śmierć Węgierskiej stanowi stratę, która dotyka zarówno pojedyncze osoby, jak i cały naród, zaś zgon poezji staje się ciosem wymierzonym nie tyle w społeczeństwo, ile w każdego człowieka z osobna ${ }^{13}$.

W przedostatniej strofie Norwid skupił się na cechach Poezji. Wyliczając jej atrybuty, nie zdefiniował, lecz tylko nakreślił jej istotę. Można w nich również odnaleźć portret samej Węgierskiej, kobiety niejednoznacznej, indywidualistki i osoby niezwykle pracowitej. Piętrząc antytetyczne porównania, zaprezentował szeroki wachlarz jej cech - uniwersalność, lecz również nieuchwytność. Podobnie samą Poezję charakteryzował w Promethidionie:

Tak jesteś — czasu ciszy; czasu burzy

Ty się zmieniasz w ton — czekasz w trybunie,

Aż się sumienie kształtem wymarmurzy,

Podniesie czoło - i fałsz w proch runie!

(PWsz III 428)

\section{Fragment z Na zgon Poezji:}

Ta monarchini i ta wyrobnica -

Zarazem wielce wyłączna i wszelka,

Ta błyskawica i ta gołębica...

(PWsz II 200-201)

W obu utworach pojawi się motyw przemiany, symbolizowany przez grom/błyskawicę. Ogień ma uderzyć w tych, którzy w wierszu będą „piaskiem zasypywać wzniosłą” (PWsz II 201). Pojawił się podział na „myśli niszczycieli” (PWsz II 201) i samotnego poetę, który przechadzał się po dziele ich zniszczenia:

Po brukowaniu się przechodząc płaskiem,

Nie jej ja depcę grób... lecz po tych dziele

Stąpam, co cmentarz wyrównali piaskiem

(PWsz II 201)

\footnotetext{
${ }^{13}$ A. Siemińska, dz. cyt., s. 464.
} 
Piasek symbolizuje to, co w swej przyziemności, jałowości i głupocie jest siłą negującą sztukę. Jak wspomniano wcześniej, powody śmierci Poezji nie są tylko czysto materialne. Główną przyczyną jest właśnie głupota i ignorancja.

Pormethidion i Na zgon Poezji różni brak nadziei na to, że cokolwiek można zmienić tu i teraz. W poemacie mowa jest o działaniu, pracy; Prometeusz wskazuje drogę odrodzenia polskiej sztuki nie przez jałowe dysputy, lecz przez czyn. W Na zgon Poezji Norwid stracił wcześniejszą nadzieję.

Antycypowana przemiana miałkiego status quo ma wymiar czysto metafizyczny. Poeta jako naznaczony potrafi przywołać ogień - żywioł zniszczenia i odrodzenia. Jednakże mające nastąpić odrodzenie, przebudzenie prometejskiego płomienia, może mieć miejsce tylko w niebie, a nie w planie rzeczywistym. Powód jest jasno podany przez poetę w sposobie, w jaki określił swych oponentów: „Aż się zamyślą myśli niszczyciele” (PWsz II 201). Czyn ten jest niemożliwym paradoksem, bowiem ci, których istotą jest niszczenie myśli, nie mogą jej w sobie rozbudzić. Marną pociechą są też słowa Prometeusza pojawiające się na kartach Promethidiona — oponenci to „bez ognia ludzie” (PWsz II 201). Heroiczny czyn nic nie zmienił i nie zmieni. Dlatego wydaje się, że w wierszu tym Norwid ukazał koniec nadziei na jakąkolwiek realną przemianę.

Pora odpowiedzieć na postawione wcześniej pytania. Poeta jest wybrańcem Poezji, jej powiernikiem, lecz również tym, który zrealizuje jej testament. W swojej twórczości zapowiada przemianę, jednakże nie tyle realną, co idealną. Według Norwida, ośrodkiem prawdziwej sztuki jest prawda. Sztuka, którą stworzy, będzie „bramą nieśmiertelności”, ponieważ oparta jest na prawdzie zyskanej przez cierpienie. Nawet jeżeli w uniwersum wiersza sztuka umiera, to jednak ma ona możliwość dostąpienia zbawienia — odrodzenia się w „Wiecznym Jeruzalem”. Może powstać jak feniks z popiołów, które są symbolizowane przez cmentarny piach. Jest to czysty idealizm, brzmiący pięknie, lecz boleśnie nierealny.

Pozostaje jeszcze jedno pytanie — dlaczego to Zofia Węgierska stała się personifikacją konającej Poezji? Przypuszczać można, że oboje mieli ten sam pogląd na niski poziom krytyki i czytelnictwa w kraju. Co więcej, uważali, że ma to związek z, jak to ujęła to pisarka, „lenistwem myśli i lenistwem serca w Polsce” (KZT II 372). To o tym właśnie napisał Norwid w Na zgon Poezji. Poza tym Węgierska bardzo często korzystała z wierszy i poglądów Norwida, umieszczając je w swoich recenzjach i sprawozdaniach. Było to efektem ich ożywionych dyskusji, które prowadzili w „Sofiówce” i w korespondencji. Można więc uznać, że elegia jest podziękowaniem Węgierskiej, a zarazem panegirykiem na jej cześć. Jej inteligencja i świetny gust musiały robić na poecie wielkie wrażenie, skoro napisał po jej śmierci, że społeczeństwo straciło jedną z najważniejszych kobiet w epoce.

Czytelnik może, nie bez powodu, uznać, że zaproponowane tu odczytanie Na zgon Poezji jest przesadnie pesymistyczne. Co więcej, może mieć wrażenie, że głównym ce- 
lem, który piszącemu przyświeca, jest ukazanie, jak Norwid radykalnie zmienił swoje poglądy oraz że istnieje głęboka przepaść pomiędzy jego wizją sztuki w Promethidionie a w analizowanym wierszu. Anna Siemińska w swojej analizie podkreśliła optymizm Norwidowskiej elegii, mówiąc o „niosących słowach nadziei” ostatnich wersach utwo$\mathrm{ru}^{14}$. Nadziei, która, jak się wydaje, jest czysto iluzoryczna. Celem autora tej analizy nie jest jednak udowodnienie, że poeta wraz z pogorszeniem sytuacji bytowej dokonał rewizji poglądów. Istotniejsze wydaje się ukazanie procesu, w którym poglądy Norwida ulegały stopniowemu pogłębianiu.

Jak już wspominano, główną ideą, wokół której osnuty jest Promethidion, jest działanie, którego cel stanowi stworzenie sztuki narodowej. Czyn nie może jednak wyrastać z samej woli zmiany, lecz również musi mieć związek z tym, co bieżące. Ten postulat został rozwinięty przez poetę w wierszu Liryka i druk z 1866 roku, utworze napisanym szesnaście lat po Promethidionie. Głównym problemem, jaki ukazał w nim Norwid, jest potrzeba wprowadzenia nowego paradygmatu Poezji. Autor podał nawet sposób, w jaki można tego dokonać:

O! żar słowa, i treści rozsądek,

I niech sumienia berło

W muzykalny łączą się porządek

Słowem każdym, jak perłą!

(PWsz II, s. 25)

To sposób, w jaki prawdziwy poeta, któremu przeciwstawiony jest „poezji drukarz”, powinien tworzyć swoje dzieła. Oto jeszcze jeden ciekawy fragment:

\footnotetext{
Treść - wypowiesz bez liry udziału

Lecz dać duchowi ducha,

Myśli myśl — to jest ciało ciału.

Cóż z tego? - martwość głucha!...

(PWsz II, s. 24)
}

Słusznie napisał Zdzisław Łapiński, odwołując się do tego fragmentu, że według Norwida:

Odrębność dwu sfer rzeczywistości ludzkiej — intelektualnej i biologicznej — musi ulec negacji. Tylko współoddziaływanie obu sfer zapewnić zdoła pokonanie owej „martwoty” ${ }^{15}$.

Słowem, Poezja według Norwida, musi być zakorzeniona w przestrzeni materialnej — w historii, socjologii oraz polityce. Stąd zapewne jego miażdżąca krytyka Mickiewicza i Krasińskiego ${ }^{16}$.

\footnotetext{
${ }^{14}$ Tamże, s. 463.

${ }^{15}$ Z. Łapiński, Norwid, Kraków 1971, s. 19.

16 „Mickiewiczowi było dano, że Mojżeszowy język gniewu narodowego lwią nasrożył grzywą, jakby bój trwał; Zygmunt Krasiński tegoż czasu sejmowy, senatorski, publiczny słowa majestat tak uprawiał, jakby
} 
W Na zgon Poezji postulat integralności sfery intelektualnej i biologicznej w Poezji nabiera szerszej perspektywy. O ile w Liryce $i$ druku Norwid odnosił się do twórców, o tyle w wierszu z 1877 roku napisał coś o samych czytelnikach. A właściwie o ich braku. Pozbawieni prometejskiego płomienia, negujący myśl, nie byli gotowi na przyjęcie Poezji opartej na prawdzie. To właśnie brak dojrzałych odbiorców, obok wymienionych w pierwszej strofie przyczyn natury materialnej, działał destrukcyjnie na Poezję i na samych twórców, których skazał na nędzę i zapomnienie. Poeta w Promethidionie wyraził nadzieję na przemianę; w Na zgon Poezji wciąż pokładał w niej wiarę, nawet za cenę utopijności.

Ogień i symbolizowana przez piach ziemia to dwa przeciwstawne żywioły. Ich zetknięcie albo uszlachetni ziemię (z piasku powstanie kryształ), albo zdusi płomień. Dla Norwida Poezja oparta na prawdzie zawsze się obroni, bo jest słuszna, bo już nawet nie tyle reprezentuje sobą ethos, co odnosi się do szerszego uniwersum — staje się theos ${ }^{17}$. Prawda dla Norwida jest zawsze wartością najważniejszą, nawet jeżeli pozostanie niedoceniona. To idea, która niezależnie od okresu jego twórczości, pozostała niezmienna.

Mateusz Grabowski

“Fire and sand" - About the Last Period of the Norwid's Life and Work
Based on Elegy Na zgon Poezji

Summary

The purpose of this article is to analyse one of the leastknown works of the poet - the elegy $\mathrm{Na}$ zgon Poezji. This is the one of the last three Norwid's works, and, moreover, the first which is opening the last period of Promethidion's author writings. Abandoned, condemned to poverty and obscurity poet is experiencing a period of deep collapse, which, however, doesn't permit him to stay silent. By reference to Norwid's works, correspondence and biography the author of this paper will try to reconstruct the least known phase of his life - the residence in the shelter of St. Casimir in Ivry.

Słowa kluczowe: Norwid, starość, poezja, zgon

Keywords: Norwid, senility, poetry, decease

za dni wielkich Rzeczypospolitej — i kłamali obydwa: Mickiewicz ów gniew narodowy, Zygmunt życie — kłamali jak niańki dzieciom chorym, powieściami bezsenne krócąc noce [...]”. Cyt. za: PWsz V 250.

${ }^{17} \mathrm{~W}$ rozróżnieniu ethos-theos odwołuję się do kontekstu bliskiemu rozważaniom Kierkegaarda zawartym w Trwodze i drżeniu. Autor Albo-albo przeciwstawia tam ethos — to, co wyraża zbiór ideałów właściwych danemu społeczeństwu — theos, czyli temu, co jest idealne w perspektywie boskiej, transcendentnej. 